\title{
INFLUENCE OF HERBAL DRUGS IN BROILER CHICKEN NUTRITION ON PRIMAL CARCASS CUTS QUALITY ASSESSEMENTS
}

\author{
Nikola M. Puvača*1,6, Ljiljana M. Kostadinović ${ }^{2}$, Olivera M. Đuragić ${ }^{2}$, Dragana B. Ljubojević ${ }^{3}$, Branislav \\ M. Miščević ${ }^{4}$, Tibor L. Könyves ${ }^{4}$, Sanja J. Popović ${ }^{2}$, Jovanka D. Lević ${ }^{2}$, Nedeljka B. Nikolova ${ }^{5}$ \\ ${ }^{1}$ University of Novi Sad, Faculty of Agriculture, 21000 Novi Sad, Trg Dositeja Obradovića 8, Serbia \\ ${ }^{2}$ University of Novi Sad, Institute for Food Technology, 21000 Novi Sad, Bulevar cara Lazara 1, Serbia \\ ${ }^{3}$ Scientific Institute of Veterinary Medicine "Novi Sad", 21000 Novi Sad, Rumenački put 20, Serbia \\ ${ }^{4}$ University of Megatrend, Faculty of Biofarming, 24300 Bačka Topola, Maršala Tita 39, Serbia \\ ${ }^{5}$ University "Ss. Cyril and Methodius", Institute of Animal Science, 1000 Skopje, Av. Ilinden 92/a, \\ Republic of Macedonia \\ ${ }^{6}$ Patent Co., 24211 Mišićevo, Vlade Ćetkovića 1A, Serbia
}

\author{
${ }^{*}$ Corresponding author: \\ Phone: +381652191284 \\ E-mail address: nikola.puvaca@gmail.com; nikola.puvaca@patent-co.com
}

\begin{abstract}
Aim of this investigation was to determine the effects of herbal drugs such as garlic, black pepper and hot red pepper in broiler chicken nutrition on carcass primal cuts quality. Total of 1200 one-day old Hubbard broilers were totally randomly distributed into eight dietary treatments with four replicates each. Chicks were fed with three dietary mixtures: starter, grower and finisher. Dietary mixtures in the experiments were as follows: T1 (Control diet), T2 (Garlic powder $0.5 \mathrm{~g} / 100 \mathrm{~g}$ ), T3 (Garlic powder $1.0 \mathrm{~g} / 100 \mathrm{~g}$ ), T4 (Black pepper powder $0.5 \mathrm{~g} / 100 \mathrm{~g}$ ), T5 (Black pepper powder 1.0 $\mathrm{g} / 100 \mathrm{~g}$ ), T6 (Hot red pepper $0.5 \mathrm{~g} / 100 \mathrm{~g}$ ), T7 (Hot red pepper $1.0 \mathrm{~g} / 100 \mathrm{~g}$ ) and T8 (Mixture of spices in ratio of 1:1:1 in total amount of $0.5 \mathrm{~g} / 100 \mathrm{~g})$. Addition of herbal drugs had significant $(\mathrm{p}<0.05)$ influence on carcass quality of broiler chickens. The highest achieved body weight of chicken was in treatment T6 $(2460.6 \mathrm{~g})$ which was followed by treatment T7 $(2442.4 \mathrm{~g})$ with statistically significant differences $(p<0.05)$ compared to other treatments. The primal cuts of the most economically important value such as drumsticks with thighs had the highest weights in treatments T7 (530.7 g), T6 (525.2 g), T2 (520.2 g) and T8 $(497.1 \mathrm{~g})$, with statistically significant differences $(\mathrm{p}<0.05)$ compared to treatments $\mathrm{T} 4, \mathrm{~T} 5$ and T1 (438.5 g, $448.7 \mathrm{~g}$ and $461.1 \mathrm{~g}$ ). When it comes to a share of primal cuts in a ready-to-grill carcass weight, significant differences were not observed ( $p>0.05)$, while significant differences in the share of wings and beck $(p<0.05)$ were recorded under the influence of added herbal drugs. It can be concluded that the addition of garlic, black pepper and hot red pepper in broiler chicken nutrition showed positive influence on chicken carcass quality.
\end{abstract}

Key words: spices, nutrition, chickens, carcass quality

\section{INTRODUCTION}

Over the past decades antibiotics as growth promoters in poultry nutrition have been used in order to improve the quality of the final product (Schwarz et al., 2001; Sarica et al., 2005; Puvača et al., 2013). Although chicken raised with addition of antibiotics achieves good productive performance on one hand, on the other hand their side effects became a real public health problem worldwide (Donoghue, 2003). To improve chicken healthiness and to fulfil consumer expectations in relation to food quality, poultry producers nowadays commonly apply natural dietary supplements mainly medical, aromatic and spice herbs (Onibi et al., 2009). The positive effects of herbal supplements or phytoadditives on broiler performance (A- 
mouzmehr and Dastar, 2009), carcass and meat quality (Khalafalla et al., 2011) have been demonstrated. The chicken products quality on the market is increa-singly valued by consumers (Vukelić et al., 2014). Garlic (Allium sativum L.) has been widely used as a herbal supplement in broiler chicken diet because of its strong stimulating effect on the immune system and the very rich aromatic oils which enhance feed digestion (Gardzielewska et al., 2003). Black pepper (Piper nigrum L.) in broiler nutrition improves health status, increases absorption of selenium, vitamin B complex, enhances the thermogenesis of lipids and accelerates energy metabolism in the body (Al-Kassie et al., 2011a). Hot red pepper (Capsicum annuum L.) plays an important role in decreasing the deposition of cholesterol and fat in the body, contributes to triglycerides level decreasing and supports the vascular system in the body (Al-Kassie et al., 2011a). All of these spice herbs exhibit antiatherosclerotic, antimicrobial, hypolipidemic, antithrombotic, antidiabetic effects (Mansoub, 2011), antioxidant, anticarcinogenic, antiinflammatory effects (Pradeep and Kuttan, 2004), chemopreventive and chemotherapeutic effects (AlKassie et al., 2011a), and also exhibit positive effects on broilers production and blood lipid profile (Puvača et al., 2015).

The aim of this study was to investigate and show the effect of natural growth promoters such as garlic, black pepper and hot red pepper in broiler chicken nutrition on chicken carcass quality.

\section{MATERIAL AND METHODS}

\section{Animals, housing and nutrition}

Biological tests were carried out under production conditions at the experimental farm "Pustara" in property of the Faculty of Agriculture, Department of Animal Science in Novi Sad and were previously described in Puvača et al. (2015). For experiment eight dietary treatments in four replicates were formed. Every dietary treatment included 150 chickens, which were divided in four pens with 37-38 chicken per each pen. For nutrition of chicks three mixtures were used, starter, grower and finisher. For the first 14 days, during the prepa- ratory period, chicks were fed with starter mixture based on the corn and soybean meal. Following the preparation period, chicks were fed with grower mixtures for the next 21 days, and then for the last 7 days of fattening period with finisher mixtures of composition and nutritive value which is given in Table 1. Dietary mixtures in the experiments was as follows: T1 (Control diet), T2 (Garlic powder 0.5 $\mathrm{g} / 100 \mathrm{~g}$ ), T3 (Garlic powder $1.0 \mathrm{~g} / 100 \mathrm{~g}$ ), T4 (Black pepper powder $0.5 \mathrm{~g} / 100 \mathrm{~g}$ ), T5 (Black pepper powder $1.0 \mathrm{~g} / 100 \mathrm{~g}$ ), T6 (Hot red pepper $0.5 \mathrm{~g} / 100 \mathrm{~g}$ ), T7 (Hot red pepper $1.0 \mathrm{~g} / 100 \mathrm{~g}$ ) and T8 (Mixture of spices in ratio of $1: 1: 1$ in total amount of 0.5 $\mathrm{g} / 100 \mathrm{~g}$ ). During the experiment chicks were fed and watered ad libitum.

\section{Samples collections}

At the end of 42 days of the experiment, 12 broiler chickens, 6 male and 6 female of an average body weight from each treatment were selected for the investtigation of carcass quality. Before slaughtering broiler chickens were starved for 12 hours, and slaughtered according to standard procedure. Immediately prior to slaughter, the broilers were weighed. Upon slaughter, dressed carcasses were subjected to measurements. Dressed cold carcasses were dissected into primal cuts such as breast, drumsticks with thighs, wings, back, head, neck and legs following the method prescribed by the Regulation on Poultry Meat Quality (1988). Primal cuts were weighed to determine the dressing percentage of the tested broilers chickens. The data obtained were used to calculate the share of individual meat classes.

\section{Statistical analyses}

Statistical analyses were conducted within statistical software program Statistica 12 for Windows, to determine if variables differed between treatments. Significant effects were further explored using analysis of variance (ANOVA) with repeated measurements, least square means (LSM) and standard errors of least square means (SELSM), as well as Fisher's LSD posthoc multiple range test with Bonferroni corrections to ascertain differences among treatment means. A significance level of $p<0.05$ was used. 
Table 1.

Composition and nutritive value of dietary mixtures $(\mathrm{g} / 100 \mathrm{~g})$

\begin{tabular}{lccc}
\hline \multirow{2}{*}{ Indices } & \multicolumn{3}{c}{ Diet mixtures } \\
\cline { 2 - 4 } Ingredients & Starter & Grower & Finisher \\
\hline Corn & & & \\
Wheat & 55.0 & 54.2 & 57.1 \\
Soybean meal, 44\% & 5.0 & 8.0 & 12.0 \\
Soy protein concentrate & 19.5 & 19.0 & 9.9 \\
Sunflower meal, 42\% & 8.8 & 5.7 & 7.8 \\
Corn gluten & 2.0 & 4.0 & 6.0 \\
Yeast & 2.0 & 2.0 & - \\
Chalk & 1.5 & - & - \\
MCP & 1.75 & 1.70 & 1.50 \\
Premix & 1.38 & 1.22 & 0.98 \\
\hline Chemical composition & 2.57 & 2.58 & 2.32 \\
\hline Dry matter & & & \\
Moisture & 89.4 & 89.3 & 10.4 \\
Crude protein & 10.5 & 10.7 & 17.3 \\
Crude fat & 21.1 & 20.7 & 4.7 \\
Crude fibre & 3.9 & 3.9 & 3.6 \\
Crude ash & 3.5 & 3.5 & 5.6 \\
Ca & 5.0 & 4.8 & 1.1 \\
P & 0.8 & 0.9 & 0.5 \\
Metabolic Energy, MJ/kg & 0.6 & 0.6 & 13.3 \\
\hline
\end{tabular}

${ }^{*}$ Spices are added on top on the basic diet

\section{RESULTS AND DISCUSSION}

From the results given in Table 2 it can be seen that the addition of herbal drugs has statistically significant $(p<0.05)$ influence on all observed parameters of broiler chicken carcass characteristics. The highest live body weight prior to slaughter and after slaughtering and cooling was observed in chickens from treatments T6 (2448.1 g; $1950.7 \mathrm{~g}$ ) and T7 (2446.8 g; $1957.1 \mathrm{~g})$ with statistically significant differences as related to the control treatment T1 (2120.0 g; $1746.2 \mathrm{~g})$. Addition of hot red pepper in amount of $1.0 \mathrm{~g} / 100 \mathrm{~g}$ led to statistically significant $(p<0.05)$ weight of ready-to-grill carcass $(1631.0 \mathrm{~g}) \mathrm{com}$ pared to the treatments T3 $(1518.2 \mathrm{~g}), \mathrm{T} 4$ and T5 (1351.7 $\mathrm{g}$ and $1418.8 \mathrm{~g}$, respectively) and also compared to the control treatment T1 (1425.2 g). The highest dressing percentage $(67.2 \%)$ was recorded in the treatment T5 and in the control treatment, while the lowest dressing percentage was recorded in treatment T4 with statistically significant differences $(p<0.05)$. According to our assumptions, addition of herbal drugs such as garlic, black pepper and hot red pepper significantly $(p<0.05)$ influenced on carcass quality of broiler chickens. The results from this study are in agreement with investigation of Fayed et al. (2011) which showed that the dietary addition of garlic in amount of $0.5 \mathrm{~kg} / \mathrm{t}$ to broiler chicken nutrition led to increased final body weights. This is also in agreement with the findings of Onibi et al. (2009) with other types of poultry. This study also showed that the addition of garlic, black pepper and hot red pepper had positive effect on production results of chickens, which is also in agreement with previous findings of Ashayerizadeh et al. (2009) with the use of garlic, black cumin and wild mint; Fadlalla et al. (2010), Stanaćev et al. (2011), Issa and Abo Omar, (2012) and Puvača et al. (2014) with the use of garlic powder; AlKassie et al. (2011a) with the use of black pepper and Valiollahi et al. (2013) with the use of black pepper and ginger in broiler chicken nutrition. As in this study, the investigation of Khalafalla et al. (2011) showed positive effects of phytogenic feed additives on the quality of broiler carcasses. 
Table 2.

Carcass characteristics of broiler chickens fed with dietary herbal drugs addition

\begin{tabular}{|c|c|c|c|c|c|}
\hline \multirow{2}{*}{\multicolumn{2}{|c|}{$\begin{array}{c}\text { Experimental } \\
\text { treatments }\end{array}$}} & \multicolumn{4}{|c|}{ Parameters } \\
\hline & & \multirow{2}{*}{$\begin{array}{c}\text { Live weight prior } \\
\text { to slaughter, } \mathbf{g}\end{array}$} & \multirow{2}{*}{$\begin{array}{c}\begin{array}{c}\text { Weight after } \\
\text { slaughtering and } \\
\text { cooling, } \mathbf{g}\end{array} \\
1746.2^{\mathrm{bc}}\end{array}$} & \multirow{2}{*}{$\begin{array}{c}\text { Ready-to-grill, } \\
\mathbf{g}\end{array}$} & \multirow{2}{*}{$\begin{array}{c}\text { Dressing, \% } \\
67.2^{\mathrm{ab}}\end{array}$} \\
\hline $\mathrm{T} 1$ & LSM & & & & \\
\hline $\mathrm{T} 2$ & LSM & $2363.7^{a}$ & $1906.2^{a}$ & $1592.3^{a b}$ & $67.2^{\mathrm{ab}}$ \\
\hline T3 & LSM & $2333.1^{a}$ & $1835.1^{\mathrm{ab}}$ & $1518.2^{b c}$ & $65.1^{\mathrm{cd}}$ \\
\hline $\mathrm{T} 4$ & LSM & $2092.5^{b}$ & $1649.8^{C}$ & $1351.7^{d}$ & $64.6^{d}$ \\
\hline T5 & LSM & $2080.6^{b}$ & $1706.0^{C}$ & $1418.8^{\mathrm{cd}}$ & $68.1^{a}$ \\
\hline T6 & LSM & $2448.1^{a}$ & $1950.7^{a}$ & $1621.1^{a}$ & $66.2^{\text {bcd }}$ \\
\hline T7 & LSM & $2446.8^{a}$ & $1957.1^{a}$ & $1631.0^{a}$ & $66.6^{\mathrm{acb}}$ \\
\hline T8 & LSM & $2360.0^{a}$ & $1894.8^{a}$ & $1564.7^{\mathrm{ab}}$ & $66.3^{b c}$ \\
\hline \multicolumn{2}{|c|}{ Pooled SE $E_{L S M}$} & 51.95 & 45.34 & 36.12 & 0.59 \\
\hline
\end{tabular}

Table 3.

Weights of carcass primal cuts $(\mathrm{g})$

\begin{tabular}{cccccc}
\hline \multicolumn{2}{c}{$\begin{array}{c}\text { Experimental } \\
\text { treatments }\end{array}$} & Breast & Drumsticks with thighs & Wings & Back \\
\cline { 2 - 6 } T1 & LSM & $482.2^{\mathrm{c}}$ & $461.1^{\mathrm{bc}}$ & $180.5^{\mathrm{bc}}$ & $301.3^{\mathrm{cd}}$ \\
T2 & LSM & $550.2^{\mathrm{a}}$ & $520.2^{\mathrm{a}}$ & $187.6^{\mathrm{ab}}$ & $334.2^{\mathrm{acb}}$ \\
T3 & LSM & $533.0^{\mathrm{ab}}$ & $478.2^{\mathrm{bc}}$ & $174.8^{\mathrm{bc}}$ & $332.1^{\mathrm{acb}}$ \\
T4 & LSM & $467.2^{\mathrm{c}}$ & $438.5^{\mathrm{c}}$ & $160.8^{\mathrm{d}}$ & $285.1^{\mathrm{d}}$ \\
T5 & LSM & $491.1^{\mathrm{bc}}$ & $448.7^{\mathrm{c}}$ & $173.0^{\mathrm{cd}}$ & $306.0^{\mathrm{bdc}}$ \\
T6 & LSM & $567.8^{\mathrm{a}}$ & $525.2^{\mathrm{a}}$ & $186.0^{\mathrm{abc}}$ & $342.0^{\mathrm{ab}}$ \\
T7 & LSM & $553.6^{\mathrm{a}}$ & $530.7^{\mathrm{a}}$ & $197.6^{\mathrm{a}}$ & $349.0^{\mathrm{a}}$ \\
T8 & LSM & $554.0^{\mathrm{a}}$ & $497.1^{\mathrm{ab}}$ & $183.2^{\mathrm{bc}}$ & $330.3^{\mathrm{acb}}$ \\
\hline \multicolumn{2}{r}{ Pooled SE } & 14.74 & 4.81 & 12.71 \\
\hline
\end{tabular}

Treatments denoted with different letters in the same column are statistically significantly different $(p<0.05)$

Table 4.

Share of carcass primal cuts in ready-to-grill carcass (\%)

\begin{tabular}{cccccc}
\hline \multicolumn{2}{c}{$\begin{array}{c}\text { Experimental } \\
\text { treatments }\end{array}$} & Breast & Drumsticks with thighs & Wings & Back \\
\cline { 2 - 6 } T1 & LSM & $33.8^{\mathrm{a}}$ & $32.3^{\mathrm{a}}$ & $12.6^{\mathrm{a}}$ & $21.1^{\mathrm{a}}$ \\
T2 & LSM & $34.5^{\mathrm{a}}$ & $32.6^{\mathrm{a}}$ & $11.8^{\mathrm{b}}$ & $20.9^{\mathrm{a}}$ \\
T3 & LSM & $35.1^{\mathrm{a}}$ & $31.4^{\mathrm{a}}$ & $11.5^{\mathrm{b}}$ & $21.8^{\mathrm{a}}$ \\
T4 & LSM & $34.5^{\mathrm{a}}$ & $32.4^{\mathrm{a}}$ & $11.8^{\mathrm{ab}}$ & $21.1^{\mathrm{a}}$ \\
T5 & LSM & $34.6^{\mathrm{a}}$ & $31.5^{\mathrm{a}}$ & $12.1^{\mathrm{ab}}$ & $21.5^{\mathrm{a}}$ \\
T6 & LSM & $35.0^{\mathrm{a}}$ & $32.4^{\mathrm{a}}$ & $11.4^{\mathrm{b}}$ & $21.0^{\mathrm{a}}$ \\
T7 & LSM & $33.9^{\mathrm{a}}$ & $32.5^{\mathrm{a}}$ & $12.1^{\mathrm{ab}}$ & $21.3^{\mathrm{a}}$ \\
T8 & LSM & $35.3^{\mathrm{a}}$ & $31.7^{\mathrm{a}}$ & $11.7^{\mathrm{b}}$ & $21.1^{\mathrm{a}}$ \\
\hline \multicolumn{2}{r}{ Pooled SE } & 0.48 & 0.27 & 0.61 \\
\hline
\end{tabular}

Treatments denoted with different letters in the same column are statistically significantly different $(p<0.05)$

Obvious influence of dietary spice addition was recorded in the weight of carcass primal cuts (Table 3). Addition of garlic, hot red pepper and mixture of herbal drugs led to statistically significant $(p<0.05)$ differences in the weight of breast meat, compared to the control and black pepper powder treatments, but without significant $(p>0.05)$ differences within the treatments. The primal cuts of the most eco- nomically important parts such as drumsticks with thighs had the highest weights in treatments T7 $(530.7 \mathrm{~g})$, T6 (525.2 g), T2 (520.2 g) and T8 (497.1 g), with statistically significant differences $(p<0.05)$ compared to treatments $\mathrm{T} 4, \mathrm{~T} 5$ and $\mathrm{T} 1$ $(438.5 \mathrm{~g}, 448.7 \mathrm{~g}$ and $461.1 \mathrm{~g})$. Weight of wings ranged between $197.6 \mathrm{~g}$ (T7) to $160.8 \mathrm{~g}$ (T4), back $349.0 \mathrm{~g}$ (T7) to $301.3 \mathrm{~g}$ (T1), respectively. 
Nasir and Grashorn (2010) confirmed positive and significant effects of the addition of two aromatic plants in broiler nutrition on weight gain, average daily weight gain, feed conversion ratio and abdominal fat percentage. Significant influence was observed in regard to carcass yield, breast percentage, crude protein content, grill losses and cooking losses. In opposite to the investigation of Nasir and Grashorn (2010) and to this study, Amouzmehr et al. (2012) showed that supplementation of garlic extracts in amount of 3.0 and $6.0 \%$ did not affect carcass characteristics including carcass yield, breast, thigh and abdominal fat. The effect of feeding broiler chicks on diets containing different levels of black pepper as natural feed additive on carcass characteristics were studied by Tazi et al., (2014); the results indicated that treatment supplemented with $1.0 \%$ of black pepper had significantly $(p<0.05)$ higher values for body weight gain, feed intake, and dressing, best feed conversion ratio, and commercial cuts percentages such as breast, drumstick and thigh.

Unlike the mass of primal carcass cuts, the share of the main cuts such as breast and drumsticks with thighs, in ready-to-grill carcass weight (Table 4) showed no significant ( $p>0.05)$ differences. In terms of the share of breasts, drumsticks with thighs and back, statistically significant differences were not observed ( $p>0.05)$. The largest share of wings in ready-to-grill carcass was recorded in the treatment $\mathrm{T} 1$ $(12.6 \%)$ which was statistically significantly different $(p<0.05)$ from those in the treatments T2 (11.8\%), T3 (11 5\%), T6 (11.4\%) and T8 $(11.7 \%)$, whereas treatments T4 (11.8\%), T5 (12.1\%) and T7 (12.1\%) were not significantly different $(p>0.05)$. Shahverdi et al. (2013) stated that drum-stick and breast percentages were increased significantly $(p<0.05)$ for broilers fed on black pepper at $0.02 \%$ level in the diet. AlKassie et al. (2011b) reported significant influence of hot red pepper to the dressing percentage which ranged from $72.0 \%$ in control group to $74.3 \%$ in group with addition $0.75 \%$ of pepper. Fayed et al. (2011) reported significant difference between the average dressing percentages, while this difference was not significant for giblet weight of the broilers fed rations with or without supplementation of garlic.

\section{CONCLUSIONS}

Based on the obtained results, it can be concluded that the addition of garlic, black pepper and hot red pepper in broiler chicken nutrition had positive effect on the chicken carcass quality. It can also be concluded that significant increase in the carcass weight after slaughtering and cooling and ready-to-grill carcass with favourable dressing percentages was influenced by hot red pepper supplementation in broiler diet, indicating hot red pepper is effective in altering the chicken body conformation. Also, the addition of garlic and hot red pepper led to significantly increased share of economically important parts of chicken carcass. The highest dressing percentage $(67.2 \%)$ was recorded in the treatment $\mathrm{T} 5$ and in the control treatment.

\section{ACKNOWLEDGEMENTS}

This paper is a result of the research within the project III 46012 "Study of modern biotechnological methods in the production of animal feed in order to increase competitiveness, quality and safety of the feed", financed by the Ministry of Education, Science and Technological Development, Republic of Serbia.

\section{REFERENCES}

1. Al-Kassie, G.A.M., Al-Nasrawi, M.A.M., Ajeena, S.J. (2011b). The effects of using hot red pepper as a diet supplement on some performance traits in broiler. Pakistan Journal of Nutrition, 10 (9), 842-845.

2. Al-Kassie, G.A.M., Al-Nasrawi, M.A.M., Ajeena, S.J. (2011a). Use of black pepper (Piper nigrum) as feed additive in broilers diet. Research Opinion in Animal and Veterinary Science, 1, 169-173.

3. Amoozmehr, A., Dastar, B. (2009). Effects of alcoholic extract of two herbs (garlic and thymus) on the performance and blood lipids of broiler chickens. Journal of Agricultural Science and Nutritional Research, 16, 62-68.

4. Amouzmehr, A., Dastar, B., Ghassemi Nejad, J., Sung, K.I., Lohakare, J., Forghani, F. (2012). Effects of garlic and thyme extracts on growth performance and carcass characteristics of broiler chicks. Journal of Animal Science and Technology, 54 (3), 185-190.

5. Ashayerizadeh, O., Dastar, B., Shams Shargh, M., Ashayerizadeh, A., Rahmatnejad, E., Hos- 
saini, S.M.R. (2009). Use of garlic (Allium sativum), black cumin seeds (Nigella sativa L.) and wild mint (Mentha longifolia) in broiler chickens diets. Journal of Animal and Veterinary Advances, 8, 1860-1863.

6. Donoghue, D.J. (2003). Antibiotic residues in poultry tissues and eggs: Human health concerns? Poultry Science, 82, 618-621.

7. Fadlalla, I.M.T., Mohammed, B.H., Bakhiet, A.O. (2010). Effect of feeding garlic on the performance and immunity of broilers. Asian Journal of Poultry Science, 4, 182-189.

8. Fayed, R.H., Abeer, H., Razek, A., Jehan, M. (2011). Effect of dietary garlic supplementation on performance, carcass traits, and meat quality in broiler chickens. Parameters, 100, 10001004.

9. Gardzielewska, J., Pudyszak, K., Majewska, T., Jakubowska, M., Pomianowski, J. (2003). Effect of plant supplemented feeding on fresh and frozen storage quality of broiler chicken meat. Journal of Polish Agricultural University, 6, 2326.

10. Issa, K.J., Abo Omar, J.M. (2012). Effect of garlic powder on performance and lipid profile of broilers. Open Journal of Animal Science, 2, 62-68.

11. Khalafalla, F.A., Fatma, H.M., Dalia, A., Zahran, A., Mosa, A.M.M.A. (2011). Influence of feed additives in quality of broiler carcasses. The Journal of World's Poultry Research, 2 (3), 4047.

12. Mansoub, N.H. (2011). Comparative effects of using garlic as probiotic on performance and serum composition of broiler chickens. Annals of Biological Research, 2, 486-490.

13. Nasir, Z., Grashorn, M.A. (2010). Effects of Echinacea purpurea and Nigella sativa supplementation on broiler performance, carcass and meat quality. Journal of Animal and Feed Science, 19, 94-104.

14. Onibi, G.E., Oluwatoyin, E., Adebisi, A., Fajemisin, N., Ayode, V., Adetun, J.I. (2009). Response of broiler chickens in terms of performance and meat quality to garlic (Allium sativum) supplementation. African Journal of Agricultural Research, 4 (5), 511-517.

15. Pradeep, C.R., Kuttan, G. (2004). Piperine is a potent inhibitor of nuclear factor-kB (NF-kB), c-Fos, CREB, ATF-2 and pro-inflammatory cytokine gene expression in $\mathrm{B} 16 \mathrm{~F}-10$ melanoma cells. International Immunopharmacology, 4, 1795-1803.

16. Puvača, N., Kostadinović, Lj., Ljubojević, D., Lukač, D., Lević, J., Popović, S., Novakov, N., Vidović, B., Đuragić, O. (2015). Effect of garlic black pepper and hot red pepper on productive performances and blood lipid profile of broiler chickens. European Poultry Science, 79, 1-13.

17. Puvača, N., Kostadinović, Lj., Ljubojević, D., Lukač, D., Popović, S., Dokmanović, B., Stanaćev, V.S. (2014). Effects of dietary garlic addition on productive performance and blood lipid profile of broiler chickens. Biotechnology in Animal Husbandry, 30 (4), 669-677.

18. Puvača, N., Stanaćev, V., Glamočić, D., Lević, J., Perić, L., Stanaćev, V., Milić, D. (2013). Beneficial effects of phytoadditives in broiler nutrition. Worlds Poultry Science Journal, 69 (1), 27-34.

19. Pravilnik o kvalitetu mesa živine (1981). Službeni list SFRJ, 1/81, 51/88.

20. Sarica, S., Ciftci, A., Demir, E., Kilinc, K., Yildirim, Y. (2005). Use of antibiotic growth promoter and two herbal natural feed additives with and without exogenous enzymes in wheat based broiler diets. South African Journal of Animal Science, 35, 61-72.

21. Schwarz, S., Kehrenberg, C., Walsh, T.R. (2001). Use of antimicrobial agents in veterinary medicine and food animal production. International Journal of Antimicrobial Agents, 17, 431-437.

22. Shahverdi, A., Kheiri, F., Faghani, M., Rahimian, Y., Rafiee, A. (2013). The effect of use red pepper (Capsicum annuum L.) and black pepper (Piper nigrum L.) on performance and hematological parameters of broiler chicks. European Journal of Zoology Research, 2 (6), 44-48.

23. Stanaćev, V., Glamočić, D., Milošević, N., Puvača, N., Stanaćev, V., Plavša, N. (2011). Effect of garlic (Allium sativum L.) in fattening chicks nutrition. African Journal of Agricultural Research, 6, 943-948.

24. Tazi, S.M.E., Mukhtar, M.A., Mohamed, K., Tabidi, M.H. (2014). Effect of using black pepper as natural feed additive on performance and carcass quality of broiler chicks. International Journal of Pharmacy Research and Analyses, 4, 108-113.

25. Valiollahi, M.R., Rahimian, Y., Miri, Y., Rafiee, A. (2013). Effect use ginger (Zingiber officenale), black pepper (Piper nigrum L.) powders on performance, some blood parameters and antibody titer against new castle vaccine on broiler chicks. Journal of Agricultural Science, 3, 535-540.

26. Vukelić, N., Živković, J., Puvača, N. (2014). Socio-demographic and lifestyle characteristics and attitudes of consumers in Vojvodina to functional food. II International Congress "Food Technology, Quality and Safety", Novi Sad, Serbia, Proceedings, pp. 397-402. 


\section{УТИЦАЈ БИЉНИХ ДРОГА У ИСХРАНИ БРОЈЛЕРСКИХ ПИЛИЋА НА ПРОЦЕНЕ КВАЛИТЕТА ВРЕДНИЈИХ ДЕЛОВА ТРУПА}

Никола М. Пувача ${ }^{* 1,6}$, Љиљана М. Костадиновић², Оливера М. Ђурагић², Драгана Б. Љубојевић ${ }^{3}$, Бранислав М. Мишчевић ${ }^{4}$, Тибор Л. Кењвеш ${ }^{4}$, Сања Ј. Поповић ${ }^{2}$, Јованка Д. Левић ${ }^{2}$, Недељка Б. Николова ${ }^{5}$

${ }^{1}$ Унверзитет у Новом Саду, Пољопривредни фракултет, 21000 Нови Сад, Трг Доситеја

Обрадовића бр. 8, Србија

${ }^{2}$ Универзитет у Новом Саду, Научни институт за прехрамбене технологије у Новом Саду,21000 Нови Сад, Булевар цара Лазара бр. 1, Србија

${ }^{3}$ Научни институт за ветеринарску медицину “Нови Сад”, 21000 Нови Сад, Руменачки пут бр. 20, Србија

${ }^{4}$ Мегатренд Универзитет, Факултет за Биофарминг, 24300 Бачка Топола, Маршала Тита бр. 39, Србија

${ }^{5}$ Универзитет "Сс. Кирил и Методије", Институт за сточарство, 1000 Скопје, Ав. Илинден бр. 92/a, Република Македонија

${ }^{6}$ Patent Со., 24211 Мишићево, Владе Ћетковића бр. 1А, Србија

Сажетак: Циљ рада је био да се испитају и установе ефекти биљних дрога белог лука, црног бибера и љуте црвене паприке у исхрани бројлерских пилића на квалитет трупа. Укупно 1200 једнодневних пилића линијског хибрида Hubbard је насумично распоређено у осам третмана, са четири понављања. Пилићи су током експерименталног периода храњени стартер, гровер и финишер смешама: Т1 (Контрола), Т2 (Бели лук 0,5 g/100g), Т3 (Бели лук 1,0 g/100g), T4 (Црни бибер 0,5 g/100g), Т5 (Црни бибер 1,0 g/100g), Т6 (Љута црвена паприка 0,5 g/100g), T7 (Љута црвена паприка $1,0 \mathrm{~g} / 100 \mathrm{~g}$ ) и Т8 (Мешавина биљних дрога у односу 1:1:1 у укупној количини $0,5 \mathrm{~g} / 100 \mathrm{~g})$. Додатак биљних дрога у храну је значајно $(p<0,05)$ утицао на квалитет трупа пилића. Највећа остварена телесна маса пилића је забележена у третману Т6 $(2460,6 \mathrm{~g})$, а потом у третману T7 $(2442,4 \mathrm{~g})$ са статистички значајним разликама $(p<0,05)$ у поређењу са осталим третманима. Највећи удео делова трупа од највеће економске важности као што су батак са карабатаком је забележен код пилића на третманима T7 (530,7 g), T6 (525,2 g), Т2 $(520,2 \mathrm{~g})$ и Т8 $(497,1 \mathrm{~g})$, са статистички значајним разликама $(\mathrm{p}<0,05)$ у поређењу са третманима T4, Т5 и T1 (438,5 g, 448,7 g и 461,1 g). Међутим, када се погледа удео важнијих делова трупа у маси трупа спремним за роштиљ, статистички значајне разлике у уделу меса груди и батака са карабатацима нису забележени ( $>0,05)$, док су статистички значајне разлике забележене $(p<0,05)$ у погледу удела крилаца и леђа пилића. На крају се може закључити да је додатак белог лука, црног бибера и љуте црвене паприке у храну испољио позитиван утицај на квалитет трупа пилића.

Кључне речи: зачини, исхрана, пилићи, квалитет трупа

Received: 18 October 2015

Accepted: 25 February 2016 